\title{
Values and Attitudes Orientation of Czech Teachers and Students Focusing on Accepting or Rejecting the Otherness of Cultural and Ethnic Minorities
}

\author{
Andrea Preissová Krejčí, Martina Cichá, Jana Máčalová \\ Palacký University, Faculty of Education, Department of Anthropology and Health Education \\ Received $6^{\text {th }}$ October 2016 / final version received $12^{\text {th }}$ February 2017 / \\ accepted $15^{\text {th }}$ February 2017
}

\begin{abstract}
This study examines the values orientation of Czech teachers and students and their attitudes towards various cultural and ethnic minorities in the Czech Republic. We believe that one of the key issues facing multicultural education is the transmission of stereotypes and prejudice among those involved in the educational process. One of the most important of our topics is also the educational process in relation to the socially disadvantaged, e.g. Roma children, children of foreigners and the like. From September 2014 to June 2015, we carried out an extensive research survey among students and teachers of primary and secondary schools in three Czech regions. The primary research objective was to provide a description of the attitudinal and values orientation of young students and their teachers towards different cultural or ethnic groups. Our expectations were confirmed in the case of a lower degree of tolerance of adolescents to the Roma minority compared to other ethnic or cultural minority groups; both the teachers and their students perceive coexistence of the majority with the Roma minority as problematic. In relation to multicultural education, we find it particularly concerning that teachers generally understand it as "learning about other cultures", which is based on emphasizing differences rather than the presentation of what they have in common. As a consequence of such an understanding, the emphasis is placed only on formation of the cognitive dimension of attitudes. Such an approach can result in promoting a stereotypical mindset of students, instead of developing critical thinking.
\end{abstract}

Keywords: attitudes, education, multiculturalism, otherness, research, values

Our study is an attempt to create a theoretically and empirically verified space designed to evoke interest in multicultural education in Czech schools. This text focuses on the practical consequences of multiculturalism in the educational process. Using empirical research, we analysed the stereotyped 
and prejudiced perception of otherness (not only ethnic otherness) which underlines the concept of multicultural education in the current Czech educational system.

A critical issue of multicultural education at Czech schools is the dissemination of stereotypes and prejudices among teachers and their young students. The results are based on the research among teachers and students of primary and secondary schools in Zlín, Olomouc and Moravia-Silesia Region implemented from September 2014 to June 2015, the aim of which was to explore attitudes of teachers and students to so-called ideas of multiculturalism. The primary research question was stated as follows: What are the attitudes and values of students in primary and secondary schools and those of their teachers towards ethnic or cultural differences?

Individuals create their values and value orientations based on acquired experience, adopted attitudes, the opinions of the past generations, and education. Values can be understood as the basis of our morals and morality. Human morality is formed in accordance with the identification of one's opinions and beliefs about what is right, good and true with the opinions of the society. It is based on the stability of our personal convictions about good, evil, and on other qualitative judgments. Even a regular and fair assessment that a teacher makes regarding the performance of their students affects the way the students create their values. The values are then fixed in the students' value orientations, leading them in a particular direction. (And vice versa.) Learning in connection with the evaluation of what we know and what we believe in creates our convictions. Human convictions do not necessarily correspond to "true" knowledge. However, they are always closely connected to human feelings and emotions. Conviction constitutes the basis of one's mental stability; it is where one's - and thus also a learner's - attitudes and actions stem from and is closely related to one's personality. If one is prepared to act in accordance with knowledge which they consider correct, they have already acquired certain beliefs, a certain worldview, and they are dedicated to certain ideas that have been internally accepted and acknowledged as right and necessary. Conviction has an undeniable impact on human understanding, learning and assessment. "A person evaluates differently when they are convinced of something." (Horák, 1997, p. 33). Our conviction is fulfilled and objectified through our attitudes and activities. Human attitudes can be generally defined as internal dispositions to react to certain objects. By this term, we mean sympathy or antipathy - affection 
or aversion to certain objects, people, groups and situations, or other identifiable aspects of the environment, including abstract ideas and social policy (Atkinson \& Atkinson, 1995, p. 727). Attitudes consist of a cognitive, affective and conative dimension (cf. Krech, Crutchfield, \& Ballachey, 1968; Nakonečný, 1999; Kosek, 2004). In other words, attitude is an evaluating relationship towards the outside world, other people, and oneself (Prücha, Walterová, \& Mareš, 2003, p. 171). It is evident that evaluation is a core feature of attitudes. It is precisely this attribute that distinguishes attitudes from opinions, which we define as statements considered to be true. They are, to a large extent, influenced by people's motives. Even though attitudes are not entirely unchangeable, they maintain a relatively high resistance to change and a fair amount of consistency. Thus, it is due to our attitudes that we act a certain way and that we tend to do so quite consistently.

It is apparent that it is very difficult to reveal the true attitudes of the respondents, especially when it comes to the attitudes towards people of different ethnicity and culture. However, it is essential that it should be possible to influence attitudes. They are subject to the influence of experience and they are influenced by social norms, respectively they adapt to them. Development of attitudes reflects the relationship of an individual to the outside world formed by their own activity. Attitudes are thus created in relationships. They are created on the basis of spontaneous learning in the family and in other social groups to which the individual belongs. Attitudes are to a large extent influenced unconsciously, by the means of unintentional learning. Our attitudes express our relationships to different values and, for the most part, they emerge from the fundamental human value system (Hayesová, 2003, p. 97; Kosek, 2004, p. 192). Therefore, both concepts must be understood as closely linked. Values work as a standard by which we judge our own behaviour and the behaviour of others; they represent what is meaningful in one's life, what they consider desirable (Nakonečný, 1998, p. 118). The primary, and simultaneously, the most demanding educational goals influence values and attitudes.

Prejudice represents a distinct type of attitudes. Prejudices are irrational, primarily adopted negative attitudes maintained by tradition directed toward someone or something. The subject of prejudice can be anything (a person or group of people, things, events). They are often directed against entire social, national and ethnic groups and in particular against "races". 
Prejudices are based on stereotypes. It is, however, necessary to differentiate between the two terms. Stereotypes are sets of schematic, preconceived assumptions and expectations concerning the behaviour and thinking of members of certain groups. Their consequence assigns certain characteristics to other well-known characteristic features, with which, however, they often have a minimal relationship. This leads to non-differentiation in relation to individual differences and specific characteristics of the individual, and to generalization. Stereotypes are not a product of the direct experience of the individual. They are taken over and maintained by tradition (Nakonečný, 1999, p. 223).

In our society, a considerable amount of prejudice is directed towards Roma people. As reported by Brod (1998, pp. 17-18), suspicion and distrust on the part of "White Czechs" against the Roma community do not originate in an inborn feeling of superiority, contempt for people of a different skin colour, nor from impassable physiological resistance to them, but instead from rather prosaic reasons: namely from negative experiences recounted over generations. Commonly held perceptions of the Roma are troubling for such people. In particular, the supposed carefree underestimation of money and competition, a "day-by-day" and "hand-to-mouth" lifestyle, communal living, independence from a particular place, etc. Moreover, the Roma themselves have prejudices towards members of the majority society. Many of them consider "White Czechs" to be people with negative moral qualities such as unjust gain, servility, greed, hypocrisy, egotism, selfishness, etc. It is crucial that the teacher does not ignore the prejudices that he or she encounters so that nationally, ethnically, racially or religiously oriented slurs or jokes, as well as any discriminatory behaviour do not stay unnoticed, without an adequate response. If the teacher does not react, he or she tacitly implies his or her agreement with the prejudice.

Therefore, among other things, the aim of our investigation was to determine the attitudes and values of teachers in relation to the ideas of multiculturalism, which we define in terms of work and pragmatically, in line with the framework educational programs such as those that lead to a conflict-free and equal coexistence of various groups with different cultures, ethnicity, religious beliefs and others. While presenting the results of our research, we then focus also on the way multicultural education is conceived and understood. With regard to the current migration situation, the approach of both teachers and the young students to members of ethnic 
or religious minorities, from which Roma were reflected the most often by the two groups, seems of crucial importance as well.

\section{Methodology}

From September 2014 to June 2015, an extensive research survey among students and teachers of primary and secondary schools in the Olomouc, Zlín and the Moravia-Silesia regions was implemented, the aim of which was to determine their value orientation and attitudes focusing on members of ethnic and cultural minority groups.

To gather our data, we devised our own questionnaire, by combining different closed-ended, half-open and open format questions, sometimes giving our respondents the possibility to substantiate other answers. The acquired data were primarily processed through the statistical methods of the SPSS program, however, in order to analyse the open-ended questions and substantiations, we also used some qualitative methods such as open coding and categorization (Skutil et al., 2011). We mainly constructed our questionnaire based on the experience that we had gained from our previous research dealing with a similar subject, which can be considered a pilot study of sorts (Preissová Krejčí, Cichá, \& Gulová, 2012). The categories that constitute the basis of our categorization were not created a priori, but emerged from a deep analysis of the open answers, that represent the superstructure of every quantitative research; where the "hard" data face their limits, open answers provide a new, different kind of information that is highly valuable for the researcher as well (Disman, 2008, p. 163; Švaříček \& Šed'ová, et al., 2014).

The creation of the research sample was based on a deliberate selection of schools with regard to their willingness or unwillingness to participate in the research. The selection of particular respondents was not affected by the researchers. Moreover, in the case of the teachers, we also used the snowball method. We are aware of the fact that a deliberate selection poses a risk to the reliability of the research. On the other hand, the risk was reduced by the total number of our respondents and the diversity of the participating schools. Our research sample consisted of 228 teachers from 26 elementary and secondary schools and 915 students from 15 elementary and secondary schools. We do not list the schools that we cooperated with in order maintain the anonymity of our respondents. Our respondents were between 24 and 
68 years of age, therefore 45 was a median value and the most frequent age was 37. Also, most of the teachers ( $85 \%$ ) were women. The average age of our students (as well as median and mode) was 14 years and the gender layout was very even with a slight superiority of women (51.1\%) to men (48.5\%). This also corresponds with the gender layout of the Czech population and therefore confirms the representativeness of our research sample (ČSÚ, 2014).

The quantitative research was enriched by the qualitative element, namely semi-structured interviews with teachers (cf. Cichá et al., 2016). We have thus reached a complex dimension of research of values and attitudes of teachers towards ethnic and cultural diversity in our society and their attitudes toward multiculturalism in the educational process. The qualitative part of the data collection involved 32 teachers ( 7 men and 25 women) from the Moravian, Zlín and Olomouc Regions.

Although the topic of the interviews was given in advance, as the selected technique of the semi-structured interviews suggests, teachers had the opportunity to express themselves to address individual questions. The main topics of our interest included, for example, the way teachers view multicultural education, whether and how they implement it, if they consider it beneficial or not, or what pros and cons of the inclusion of multicultural education into the education programs they see. The task was also to find out not only the way teachers perceive the topics of multicultural education, but also their opinion on the way these topics are perceived by their young students. All the interviews were recorded on a dictaphone and then transcribed into a text document. A subsequent analysis was carried out in software for processing qualitative data Atlas.ti. Here, we subjected the transcribed conversations to open coding, the basic technique used when processing qualitative data. At this stage, an initial interpretation of the data was implemented while sorting open coding into 85 codes Those were the codes revealed in the course of repeated reading.

We then categorized these codes, grouping them according to their internal relationships, similarity or continuity and created 10 subcategories, from which 3 main categories were developed within the process. These include the categories of (1) Multicultural education, (2) Roma and (3) School and influences outside the school. Multicultural education is considered to be the main category because it contains almost all the answers to the questions we 
asked. However, the other two categories cannot be totally separated from the central category because they are all interrelated and complementary. Without them, the results would lose their plasticity, sometimes they could even be considered of lesser informative value.

\section{Research results}

Some of the questions in the both types of the questionnaires in some points matched because of their possible comparison. The questionnaire starts with few identification questions, followed by the content questions which we can differentiate as (a) those, that are determining the respondents' attitude towards foreigners or specific ethnic and cultural groups and (b) those, that are determining the attitude of other people towards foreigners or specific ethnic and cultural groups as they were mediated by our respondents. Firstly, we focus our attention on which general values our students and teachers consider the most important and less important. Thereafter, we will analyse their attitudes towards specific ethnic or religious groups.

The young students chose Friendship and fellowship as the most important values in $71.6 \%$ and as rather important in further $19.8 \%$. Furthermore, the respondents chose the value of Love and partnership as the most important in $66.6 \%$ and rather important in $22.2 \%$. Tolerance to different sexual orientation was mostly categorized as of little importance in $10.8 \%$ and in $8.2 \%$ as the least important.

Teachers marked mostly Love and partnership (63\%), Sense ofjustice (60.8 \%) and Friendship and fellowship (55.5\%) as the most important values. The most preferred values also included the Ability to communicate (the sum of the answers the most important and quite important amounted to $95.2 \%$ ), the Ability to help the ones in need (92.9\%), Tolerance towards advanced age and the elderly (91.1\%), and Protection of the disadvantaged ones (89.8\%). The categories Recognition of the majority (17.9\%), Tolerance to different sexual orientation ( $8.9 \%)$ and Tolerance to different appearance (8\%) were marked as of little or the least importance.

In the case of teachers, as well as in the case of students, all the evaluated values relate to personal relationships among individuals. Less appreciated values appear to be related to general tolerance to otherness, unique identity of persons and their mutual differences, which include different sexual orientation, different appearance and so on. 
We find it alarming that both teachers and students reported that Czechs generally expect members of different ethnic or cultural groups to adjust. Moreover, both participant groups admit that Czechs are hostile and even racist towards other ethnicities and minority groups (Figure 1). While most teachers and nearly a half of the students consider their personal relationship to ethnic or cultural minority groups to be neutral (Figure 2), which means de facto positive, they see the Czech society as negatively oriented or even xenophobic.

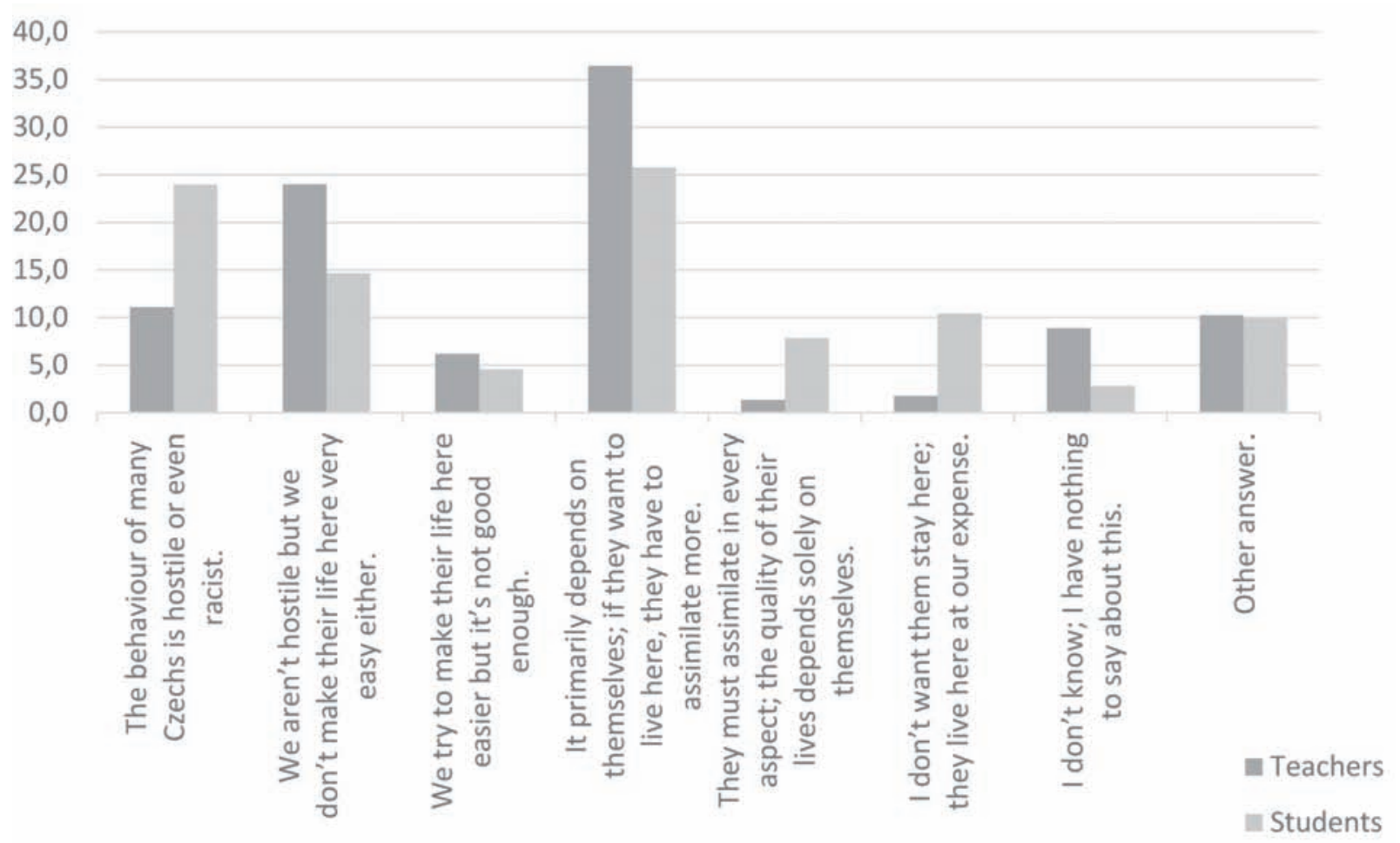

Figure 1. The relationship of Czech society towards members of different ethnic and cultural minorities as assessed by the respondents (responses to one questionnaire item; in \%). 


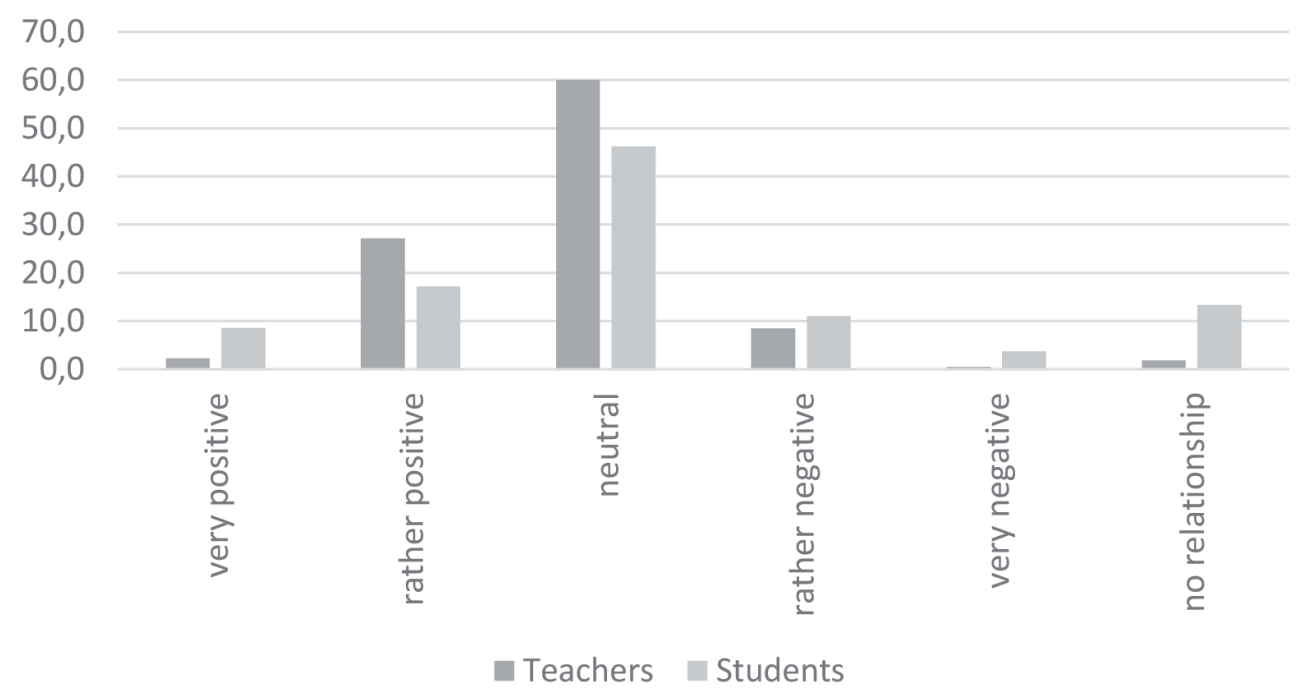

Figure 2. Personal relationship of the respondents towards members of other ethnic and cultural groups (in \%).

This may not be surprising, yet it can be potentially threatening to a conflictfree coexistence of the majority with minority groups, because if the society is perceived as negatively-oriented, it becomes difficult for an individual to express their views that are not consistent with the putative mainstream. We believe that for many teachers it is rather difficult to stand up against negative attitudes and opinions of the majority society, albeit supposed ones, and they prefer abstaining from expressing their opinion or speaking out against attitudes shared by the students and their families and the mediaconstructed reality.

We asked our respondents by the means of a semi-closed question about their personal relationship towards various ethnic or cultural groups. The question was divided according to selected groups: people from Asia, the former Soviet Union, the Balkans, Africans, African-Americans, Arabs, Muslims, Jews, Roma, Poles and Germans.

In both teachers and students, neutral opinions vastly prevail. However, their attitudes towards the Roma population radically stand out compared with other minority groups included in the survey. Proportionally, responses expressed by both teachers and students regarding the Roma are rather negative or very negative with the students being more radical than their teachers. 
In order to compare the attitudes of our respondents towards the Roma and the other selected groups, we determined the "average" attitudes of the respondents (cf. Moravcová, 2016; Preissová Krejčí et al., 2016), which was possible thanks to the fact that the question was designed as a scale (Gavora, 2008, pp. 115-116). We used the following coefficients to mark each item on the scale: (1) very negative, (2) rather negative, (3) neutral, (4) rather positive, (5) very positive. Using these coefficients, we were able to calculate the mean of the attitudes towards individual groups, which shows a clear difference between the expressed attitudes towards the Roma and the attitudes towards the other groups (Table 1 and Table 2).

Table 1

Attitudes of the teachers towards selected groups (mean)

\begin{tabular}{|c|c|c|c|}
\hline Groups & Mean & Groups & Mean \\
\hline People from Asia & 3.45 & Arabs & 2.78 \\
\hline The former Soviet Union & 3.24 & Jews & 3.62 \\
\hline The Balkans & 3.14 & Roma & 2.48 \\
\hline Africans & 3.26 & Poles & 3.62 \\
\hline African-Americans & 3.34 & Germans & 3.55 \\
\hline
\end{tabular}

Table 2

Attitudes of the students towards selected groups (mean)

\begin{tabular}{|c|c|c|c|}
\hline Groups & Mean & Groups & Mean \\
\hline People from Asia & 3.57 & Arabs & 2.97 \\
\hline The former Soviet Union & 3.24 & Jews & 3.25 \\
\hline The Balkans & 3.36 & Roma & 2.21 \\
\hline Africans & 3.61 & Poles & 3.39 \\
\hline African-Americans & 3.71 & Germans & 3.57 \\
\hline
\end{tabular}

Also, negative attitudes among students and teachers towards Muslims and Arabs are not to be disregarded. Moreover, the students display mostly unjustified negative attitudes toward Jews - a phenomenon which surely deserves a more comprehensive survey.

The reason being Roma's frequent association with contexts and situations that do not come as a surprise to the majority population. Therefore, we extended our inquiries into this kind of perception of the Roma minority. 
In follow-up, specifying questions, often of an open-sentence character, we were able to gradually uncover the general idea of how Romani students behave, look, and study according to both groups of respondents. The teachers assumed that their students have a negative attitude toward the Roma and that their behaviour in this respect is influenced by prejudice. Nevertheless, the teachers themselves mostly share these anti-Roma prejudices and negative attitudes with the majority. It is even more absurd as their own experience with the presence of Roma pupils in class was not always problematic. Many of them characterise their Roma pupils as problem-free, zealous, successfully integrated, but these successful Romani pupils are hardly perceived as typical, in essence "they are not the real Roma". The Roma who do not conform to the stereotypical view are exempt from their own ethnic category and do not affect the prejudicial behaviour of teachers and their pupils towards this group. Moreover, the teachers blame the students' extracurricular environment, i.e., the parents and peers for adopting negative attitudes towards the Roma. Although the Roma minority is perceived as problematic by both students and teachers, it can be stated with some relief that teachers tend towards a more neutral stance and do not hold a dominantly negative opinion of the Roma. Some hope of change may also be identified in teachers' self-evaluation in which they acknowledge that the issue of multicultural education is largely difficult for them, especially with regard to coexistence with the Roma population against which they themselves hold certain prejudice. As a result, they self-critically admit that in such a case they cannot effectively work with the stereotypes and prejudices of their students.

\section{Discussion}

Our findings may not be particularly surprising or innovative. But how is it possible that all the attempts to reduce the social tension between the majority and the Roma have been unsuccessful? What is the cause of the long-term lack of success of Czech teachers in trying to fulfil the goals of multicultural education? We attempt to suggest alternative solutions.

The experts (Hirt, 2005, p. 10; Morvayová \& Moree, 2009, p. 6; Preissová Krejčí, 2016, p. 10; 2014; Tesař, 2007, p. 92, etc.) have long been concerned with the problematic understanding of multicultural education at Czech schools, based on the concept of classic multiculturalism, which assumes that there are objective and fixed boundaries between different groups and, 
therefore, emphasizes the dichotomy of the groups of "us" and "them". The multicultural education that stems from these ideas tends to encourage a stereotypical and prejudiced way of thinking and xenophobic or even discriminatory behaviours.

The classic understanding of the ideas of multiculturalism is based on socalled pluralist or differential multiculturalism, which in turn rests on the idea that there are natural and insuperable boundaries between groups (Baršová \& Barša, 2008, p. 51). In contemporary social sciences, however, so-called critical multiculturalism is opposed to these concepts. It "demands a fundamental reconstruction of the conceptual, political and practical tools that have been developed within the framework of multiculturalism" (Hirt, 2005 , p. 13). This form of multiculturalism, which deals with the topics of power, dominance, privileged and the marginal status of different groups or the creation of racial, class and gender inequality etc. (May \& Sleeter, 2010, pp. 10-11; Steinberg, 2009, pp. 5-6), has not been widely discussed in the Czech environment and, therefore, has not been reflected in the educational process. That is in spite of the fact that one of the goals of critical multiculturalism is to rethink the content of school curricula so that they do not reproduce the meaning structures created by the dominant culture (Hirt, 2007, p. 58). Critical multiculturalism strives to extend the critical dialog both across the borders separating various ethnic, cultural, etc. groups and within the groups themselves (Eriksen, 2012, p. 241). For that reason, it emphasizes an individual approach.

Both of the antagonistic forms of multiculturalism are reflected in the different approaches to multicultural education, as defined by Dana Moore et al. (2008). The first of these approaches is the culturally-standard approach, based on the pluralist form of multiculturalism, which gained popularity in the Czech Republic in the 1990's, both on the national and educational level, and remains the most popular approach to this day. Its key element is the belief that the actions of an individual cannot only be explained but also be anticipated based on the knowledge of the history and cultural practice of the group which the individual is a member of (Moore et al., 2008, pp. 23-26). This approach employs the reductionist concept of multicultural education. Therefore, the essential limitations of this approach are the tendency to describe sociocultural units as homogenous and static groups and the narrow selection of the information that is chosen to be passed on to the students. 
The majority of the teachers participating in our research, presumably influenced by the form of multiculturalism described above, agree that multicultural education is necessary and that it should primarily develop positive relations among different cultures while serving as prevention against racist and extremist behaviour. Although accentuation of this objective points out to society's general understanding of the issue within the discourse described as a "culturally standard" approach to multicultural education, we found a number of teachers among our respondents who realise the problematic nature of this concept and who also associate it with a broader thematic scope including ageism, gender, social exclusion, physical or mental disability, etc.

The second alternative is the transcultural approach which primarily focuses on establishing the themes that different groups have in common and using cooperative strategies (Moree et al., 2008, p. 13). It questions the culturally standard approach and brings up various topics that go beyond its framework. In that sense, we can consider it a broader or an overarching concept of multicultural education (see Preissová Krejčí, 2016).

Let us no longer convince pupils and students that different cultures and ethnic groups can coexist peacefully side by side in a multinational community. It is just as unwise as emphasizing the otherness of some compared to others and expecting that such labelling will not lead to underlining of their differences and possible exclusion from the majority community. This wider understanding of multicultural education, which Dana Moree calls a transcultural approach, may soon help and create a school climate tolerant of those who generally differ from the majority based on their anthropo-racial and other categories. Should we manage to shift human diversity into the centre of our interest with the assistance of multicultural education, we move the boundaries of imagination and empathy of our youth (and not only them). In doing so, we will also help eliminate discrimination based on gender, age, handicaps, etc., which will greatly benefit the future Czech society.

According to Dana Moree, there is a simple tool that can help determine which of the two approaches a teacher is inspired by. If their teaching mainly focuses on the minorities (the Roma, Czechs, Vietnamese or e.g. gays and lesbians), it often leads to a stereotypical depiction of the entire groups and it suggests that the teacher leans towards the culturally standard approach 
of multicultural education (Moree, 2015, p. 177). However, if the teaching is mainly focused on the topics concerning intercultural relationships, such as culture, conflict, identity, communication etc., the teaching is probably influenced by the transcultural approach.

Most teachers of multicultural education who participated in our research, however, understand the overarching concept for the development of tolerance as only ethnic diversity, not including gender, age, disability, social status, sexual orientation, etc. Their primary understanding of multicultural education is learning about other cultures based on the dichotomy of "us" and "them" rather than emphasizing shared human characteristics or helping their students realise differences on the individual level. Such an approach results in formation of only one of the three dimensions of attitudes - the cognitive one. This method of multicultural education along with other described factors (teachers' lack of argumentative skills, imposing multicultural ideas by "forcing" them, or stereotypical assumptions about certain minority groups held by the teachers themselves, etc.) goes against the spirit of multicultural education as formulated in the framework educational programmes due to the fact that this way it merely strengthens stereotypical thinking in students rather than replacing it with critical thinking - the development of which is essential in the contemporary media-influenced society (cf. Grecmanová \& Urbanovská, 2007; Preissová Krejčí, 2014).

\section{Conclusion}

The acceptance of the ideas of multiculturalism, especially through the process of education, seems quite remote to the contemporary Czech society. Our empirical research reveals the attitudes of teachers and their students towards members of minority groups that we can consider ambivalent or even negative in the case of the Roma.

The attitudes identified in our research in both students and teachers may to some extent reflect the inclination of their bearers toward xenophobia and racism, as certain stigmatization of the Roma people in the public space of the Czech Republic is generally shared. The findings clearly show that the "Roma" issues are still alive and equally complex in contemporary Czech society, which is also true from the perspective of teachers themselves. 
We can say that the values and attitudes of adolescents regarding their perception of members of different culture or ethnicity are not entirely different from the values and attitudes of their teachers. Different ethnic groups are generally seen as homogeneous entities that are culturally distinct from the majority, thus bearing the mark of "otherness" and attracting stereotypical assumptions.

It is apparent that the attitudes of teachers and students are influenced by their interaction. Therefore, we believe that multicultural education should not only be directed at students but also - and perhaps even more urgently at their teachers. Despite other influences (such as family environment, media etc.), the teacher represents the basic factor that determines the quality of multicultural education. However, it seems to be difficult for the teachers to stay neutral in the class when they hold negative attitudes towards members of minority groups that they are supposed to depict in a positive way (cf. Máčalová, 2014, p. 261; Preissová Krejčí, 2016, p. 81). A one-sided presentation, regardless of its inclination towards the negative or the positive part of the spectrum, does not correspond with the reality. Life-long education of teachers in the field of multiculturalism is becoming a necessity.

It is essential that the teacher first gains an insight into multicultural issues. Only then will they be able to encourage their students to adopt "multicultural values" in the sense of tolerance of each individual as a unique human being (Moree, 2015; Preissová Krejčí, 2016).

Students who - influenced by the culture they come from - somehow differ from the majority (e.g., by their language competencies, different learning capacities, etc.) require special teaching strategies that would allow them to compensate for their difficulties. We believe that it is the teachers - through understanding and a supportive approach to these students - who encourage the youth to become citizens participating in all spheres of social life (Sleeter \& Grant, 2009, p. 43). In this spirit, it is necessary for teaching to reflect various topics that may be linked to stereotypes or biased behaviour caused by different socio-economic backgrounds, different sexual orientations, but also, for example unusual fashion style, etc. These aspects are present in the everyday reality in classes. Therefore, in their undergraduate and postgraduate training teachers must acquire multicultural competencies and learn to work with the "multicultural" potential of their class. 
The ambivalent attitude of our respondents towards members of minority groups stems from misunderstanding and unwillingness to try and understand the "normality of otherness". This attitude also stems from the lack of effort not to portray otherness as something strange and peculiar.

If we teach our children and teens tolerance and empathy towards people with different forms of handicap, different sexual orientation, etc., then we are just a step from their accepting human diversity as a natural quality, including other visible differences in people from other continents, or people of different faiths.

Effective influencing of the values and attitudes of students leading towards tolerance and empathy cannot be achieved unless the teachers are ready to accept the complicated task and meet the requirements of inclusive education (Morvayová \& Moree, 2009, p. 19).

Therefore, it seems crucial to develop the multicultural competencies of the teachers, to expand their knowledge but also to influence their values and attitudes towards otherness. The teachers tend to diminish their influence on the students (Kusá, 2012). One of the objectives of their further education should be, among others, to show them some successful examples of multicultural education in foreign countries that will prove to them that they can actually influence their students and that multicultural education can be effective (DomNwachukwu, 2010; Manning \& Baruth, 2009).

\section{References}

Atkinson, R. L., \& Atkinson, R. C. (Eds.). (1995). Psychologie. Praha: Viktoria Publishing.

Baršová, A., \& Barša, P. (2008). Integrační politiky: mezi asimilací a multikulturalismem. In T. Šišková (Ed.), Výchova $k$ toleranci a proti rasismu: Multikulturní výchova $v$ praxi (pp. 48-58). Praha: Portál.

Brod, T. (1998). Několik úvah a poznámek na dané téma In P. Žantovský (Ed.), Česká xenofobie (pp. 17-24). Praha: Votobia.

Cichá, M., Máčalová, J., Moravcová, B., Preissová Krejčí, A., Prokeš, M., \& Roubínková, M. (2016). Romové očima pedagogů základních a středních škol. Antropowebzin, 2016(1-2), 21-30.

ČSÚ. (2014). Obyvatelstvo podle pohlaví, věku a rodinného stavu [on-line]. Retrieved from https://www.czso.cz/documents/10180/20541835/30000414k01.pdf/1a3310e8-ed0f43f6-a0c7-f5871b963cb2?version=1.1.

Disman, M. (2008). Jak se vyrábí sociologická znalost. Praha: Karolinum.

DomNwachukwu, C. S. (2010). An introduction to multicultural education. Lanham: Rowman \& Littlefield Publishers.

Eriksen, T. H. (2012). Etnicita a nacionalismus: antropologické perspektivy. Praha: SLON. 
Gavora, P. (2008). Úvod do pedagogického výskumu. Bratislava: Vydavatel'stvo UK.

Grecmanová, H., \& Urbanovská, E. (2007). Aktivizační metody ve výuce, prostředek ŠVP. Olomouc: Hanex.

Hayesová, N. (2003). Základy sociální psychologie. Praha: Portál.

Hirt, T. (2005). Svět podle multikulturalismu. In T. Hirt \& M. Jakoubek (Eds.), Soudobé spory o multikulturalismus a politiku identit (pp. 9-76). Plzeň: Aleš Čeněk.

Hirt, T. (2007). Přehled myšlenkových proudů a kritik multikulturalismu. In P. Rosůlek (Ed.), Politická filozofie: Aktuální problémy (pp. 42-62). Plzeň: Aleš Čeněk.

Horák, J. (1997). Škola a hodnotová orientace dětí a mládeže. Liberec: Technická univerzita.

Kosek, J. (2004). Člověk je (ne)tvor společenský: kapitoly ze sociální psychologie. Praha: Argo.

Krech, D., Crutchfield, R. S., \& Ballachey, E. L. (1968). Človek v spoločnosti. Bratislava: Vydavatel'stvo Slovenskej akadémie vied.

Kusá, J. (2012). Pedagogická reflexe multikulturní výchovy při práci s literárními texty na 2. stupni základních škol (Disertační práce). Olomouc: UP.

Máčalová,J.(2014). Multikulturalismus ve školnípraxi: náhled pedagogů. InJ. Husár, M. Machalová, T. Hangoni, \& B. Kuzyšin (Eds.), Nová sociálna edukácia človeka III. (pp. 256-262). Prešov: Prešovská univerzita.

Manning, M. L., \& Baruth, L. G. (2009). Multicultural education of children and adolescents. Boston: Pearson.

May, S., \& Sleeter, C. E. (2010). Critical multiculturalism. New York: Routledge.

Moravcová, B. (2016). Reflexe multikulturalismu ve sdílených hodnotách učitelů a žáků (Diplomová práce). Olomouc: UP.

Moree, D. (Ed.). (2008). Než začneme s multikulturní výchovou: od skupinových konceptů k osobnostnímu prístupu. Praha: Člověk v tísni.

Moree, D. (2015). Základy interkulturního soužití. Praha: Portál.

Morvayová, P., \& Moree, D. (2009). Dvakrát měř, jednou řež. Praha: Člověk v tísni.

Nakonečný, M. (1998). Psychologie osobnosti. Praha: Academia.

Nakonečný, M. (1999). Sociální psychologie. Praha: Academia.

Preissová Krejčí, A. (2014). Multikulturalismus - ztracené paradigma? Olomouc: Univerzita Palackého.

Preissová Krejčí, A. (2016). Za hranice multikulturalismu. Olomouc: Univerzita Palackého.

Preissová Krejčí, A., Cichá, M., \& Gulová, L. (2012). Jinakost, předsudky, multikulturalismus: Možnosti a limity multikulturní výchovy. Olomouc: Univerzita Palackého.

Preissová Krejčí, A., Máčalová, J., Cichá, M., \& Moravcová, B. (2016). Migrace, integrace a česká škola. Paidagogos, 2016(1), 70-89.

Průcha, J., Walterová, E., \& Mareš, J. (2003). Pedagogický slovník. Praha: Portál.

Skutil, M. (Ed.). (2011). Základy pedagogicko-psychologického výzkumu pro studenty učitelství. Praha: Portál.

Sleeter, C. E., \& Grant, C. A. (2009). Making choices for multicultural education. Five approaches to race, class, and gender. New York: John Willey \& Sons.

Steinberg, S. R. (2009). Diversity and multiculturalism: A reader. New York: Peter Lang.

Švaříček, R., \& Šed’ová, K., et al. (2014). Kvalitativní výzkum v pedagogických vědách. Praha: Portál.

Tesař, F. (2007). Etnické konflikty. Praha: Portál. 


\title{
Authors
}

Mgr. Andrea Preissová Krejčí, Ph.D., Palacký University, Faculty of Education, Department of Anthropology and Health Education, Žižkovo nám. 5, 77147 Olomouc, Czech Republic, e-mail: andrea.preissova@upol.cz

doc. Mgr. Martina Cichá, Ph.D., Palacký University, Faculty of Education, Department of Anthropology and Health Education, Žižkovo nám. 5, 77147 Olomouc, Czech Republic, e-mail: martina.cicha@upol.cz

Mgr. Jana Máčalová, Palacký University, Faculty of Education, Department of Anthropology and Health Education, Žižkovo nám. 5, 77147 Olomouc, Czech Republic,

e-mail: jana.macalova01@upol.cz

\section{Hodnotová a postojová orientace českých učitelů a žáků se zaměřením na přijetí, respektive odmítnutí jinakosti kulturních a etnických minorit}

\begin{abstract}
Abstrakt: Studie zkoumá hodnotovou orientaci českých učitelů a studentů a jejich postoje k rozličným kulturním a etnickým minoritám v České republice. Domníváme se, že klíčovým problémem multikulturního vzdělávání je sdílení stereotypů a předsudků mezi účastníky edukačního procesu. Pro naše téma je nejdůležitější výchovně vzdělávací proces ve vztahu k sociálně znevýhodněným, kterými jsou např. romské děti, děti cizinců apod. Od září 2014 do června 2015 jsme realizovali rozsáhlé výzkumné šetření mezi žáky a učiteli základních a středních škol ve třech krajích České republiky. Hlavní výzkumný záměr spočíval ve zjištění a deskripci postojové a hodnotové orientace žáků a jejich učitelů vůči odlišným kulturním či etnickým skupinám. Naše předpoklady se potvrdily $v$ případě nižší míry tolerance adolescentů k romské minoritě ve srovnání s ostatními etnickými či kulturními menšinovými skupinami, pedagogové i žáci vnímají soužití majority s romskou menšinou jako problematické. Ve vztahu k multikulturní výchově jsme dospěli ke znepokojujícímu zjištění, že pod ní učitelé obecně rozumí „učení se o jiných kulturách“, tzn. že se zdůrazňují rozdíly, namísto toho, aby bylo prezentováno, co mají tyto kultury společného. Důraz je tak kladen pouze na formování kognitivní složky postojů. Takový přístup vede k posilování stereotypního myšlení žáků, namísto rozvoje kritického myšlení.
\end{abstract}

Klíčová slova: postoje, vzdělávání, multikulturalismus, jinakost, výzkum, hodnoty 